\title{
Analysis of the bearing behaviour of a screw-pile foundation in silt soil
}

\section{Pengcheng Jiang MA}

PhD candidate, Department of Geotechnical and Underground Engineering, School of Civil Engineering, Lanzhou Jiaotong University, Lanzhou, China (corresponding author: 15393172895@163.com) (Orcid:0000-0002-7114-9406)

\section{Wang Xu PhD}

Professor, Department of Geotechnical and Underground Engineering School of Civil Engineering, Lanzhou Jiaotong University, Lanzhou, China (Orcid:0000-0003-4678-1570)
Yanjie Zhang PhD

Associate Professor, Department of Geotechnical and Underground Engineering, School of Civil Engineering, Lanzhou Jiaotong University, Lanzhou, China (Orcid:0000-0002-9969-377X)

Screw-pile composite foundations have been widely implemented on multiple high-speed railways in China. Their distinctive design with variable sections makes the bearing behaviour of screw piles far more complex than that of common smooth piles. The bearing behaviour of a screw-pile composite foundation was analysed in silt soil on a national key construction project. A comparative analysis of the bearing characteristics of composite foundations of smooth piles and screw piles was performed through model tests. The results showed that, in a single-pile composite foundation and with the same pile diameter and length, the ultimate bearing capacity of the screw pile was $67 \%$ higher than that of the smooth pile. The smooth pile showed an area of negative frictional resistance at the top of the composite foundation. The screw pile had a negative friction area below the junction of the smooth section and the screw section in the screw-pile composite foundation.

$\begin{array}{ll}\text { Notation } \\ b & \text { thickness of screw blade } \\ D_{1} & \text { pile diameter } \\ D_{2} & \text { screw section diameter } \\ D_{3} & \text { width of screw } \\ h & \text { pitch of screw blade } \\ L & \text { pile length } \\ L_{1} & \text { smooth section length } \\ L_{2} & \text { screw section length } \\ p & \text { axial pressure } \\ Q & \text { axial load } \\ s & \text { vertical settlement } \\ t & \text { test time }\end{array}$

\section{Introduction}

A screw pile is a variable-section pile that possesses a cylindrical upper part and a threaded lower part. Relative to full-screw filling piles and ordinary mud-retaining piles, screw piles have the advantages of high bearing capacity, wide applicability, fast pile forming, flexible size, no noise and no vibration, and have been widely used in the foundations of high-rise buildings. Relative to the cement-fly-ash-gravel piles and pipe piles commonly used in railway engineering, screw piles offer advantages such as the high bearing capacity of a single pile, low unit cost and so on, and have been applied in multiple high-speed railway projects such as the Beijing-Shanghai, ShijiazhuangJinan, Harbin-Mudanjiang and Zhengzhou-Xuzhou passenger railways currently operating in China (Deng, 2016; Liu, 2015; Wan, 2016).

Along with large-scale applications of screw piles, the bearing capacity of screw piles has received recent research attention.
Rao et al. (2008) investigated model piles screwed into soft-tomedium stiff clay beds prepared in a test tank. Standard types of loading frames were constructed for effecting both compressive and tensile forces. Kurian and Shah (2009) conducted research on the bearing characteristics of screw piles under compressive, tensile and lateral loading conditions using the finite-element method. Sakr (2009) conducted comprehensive pile load-test programmes and observations from field monitoring of helical piles with either a single helix or double helixes installed in oil sand. The test results confirmed that the helical pile is a viable deep-foundation option to support heavily loaded structures. Stanier et al. (2014) used transparent synthetic soil and particle image velocimetry to observe the failure of helical screw piles with helical plate spacing ratios of 1.5-3.0 and active lengths up to three times the diameter. Lee et al. (2016) conducted laboratory tests, field load tests and three-dimensional (3D) finite-element analyses of prebored screw piles. The results showed that the ultimate bearing capacity and the unit skin friction of the screw pile were substantially superior to those of a smooth-surfaced pile. By means of anti-tension model tests, parameters of the blade width ratio were presented, the ground stress of the screw-pile foundation during loading was measured and the load-transfer relationship between the blade and the foundation was studied (Dong et al., 2008). To examine the vertical loadbearing characteristics of screw piles in sand, indoor model tests were conducted and the influence of the pitch on the bearing capacity of screw piles was evaluated through a comparative analysis of the differences in bearing performance between a screw pile and an ordinary smooth pile (Meng et al., 2012). Qian et al. (2015) performed model tests and 3D finite-element analyses to calibrate the load-displacement 
responses and the characteristic distributions of skin friction. Experimental observations have demonstrated that, due to certain occlusion effects between the screw and soil, a screwed pile produces a strongly increased ultimate uplift-bearing capacity with respect to a circular pile.

Due to its unique variable cross-section design, the work and load-bearing mechanism of screw piles are more complex than those of common smooth-rod piles. This study on the bearing capacity of a screw pile focuses on static load test results. A modified and simplified formula is based on calculation of the bearing capacity of a conventional pile foundation. Due to the late start and slow progress of research on the bearing properties of screw piles, research on the bearing mechanism is not yet advanced.

Composite foundations are used to reinforce a soft foundation, which means installing structures with high stiffness into the soil so that the soft ground can be supported by the installed structures and surrounding soil. Pile technology has been widely used in soft ground improvement. Considering the national key construction project of a new railway from Hohhot to Zhungeer, comparative analyses of the bearing capacity of smooth piles, screw piles and pile composite foundations were conducted using indoor model tests and numerical simulation. This project represents the first application of screw piles in a soft soil area and provides a technical reference for the foundation treatment of railway engineering in particular regional areas of China.

\section{Model test design}

The size of the model box was $120 \mathrm{~cm} \times 120 \mathrm{~cm} \times 120 \mathrm{~cm}$ (length $\times$ width $\times$ height). The model piles consisted of PTFE nylon rods with an elastic modulus of $2.65 \mathrm{GPa}$. The geometric similarity ratio of the model pile was $10: 1$. The length of the pile was $L=800 \mathrm{~mm}$ and the pile diameter was $D_{1}=50 \mathrm{~mm}$. The length of the screw section was $L_{2}=500 \mathrm{~mm}$ and the length of the smooth section was $L_{1}=300 \mathrm{~mm}$. The diameter of the screw section was $D_{2}=30 \mathrm{~mm}$ and the thickness of screw blade was $b=5 \mathrm{~mm}$. The width of the screw was $D_{3}=10 \mathrm{~mm}$ and the pitch was $h=35 \mathrm{~mm}$. A schematic diagram is presented in Figure 1. Ten strain gauges were positioned along the axis of the pile layout, as shown in Figure 2. Paste epoxy resin was used to adhere $1-2 \mathrm{~mm}$ sand around the pile to produce a rough surface.

In the model test, remoulded Lanzhou silt soil was used as the fill. The physical and mechanical parameters are shown in Table 1. A total of ten smooth piles and ten screw piles were used; the rows were arranged in five rows and four columns, two columns of smooth piles and two columns of screw piles $(20 \mathrm{~cm})$, and the vertical pile spacing was three times the pile diameter $(15 \mathrm{~cm})$, as shown in Figure 3. Piles 1, 2, 5 and 6 were used for pile bearing capacity tests and piles $3,4,7$ and 8 were used for single-pile composite foundation bearing

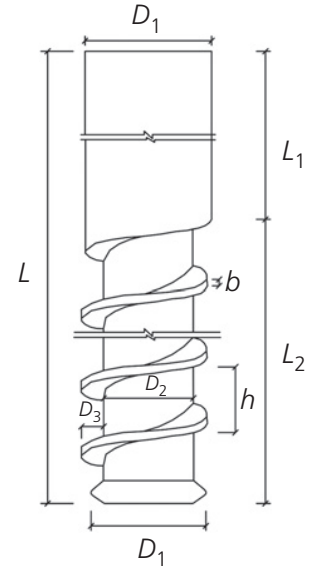

Figure 1. Schematic illustration of screw pile

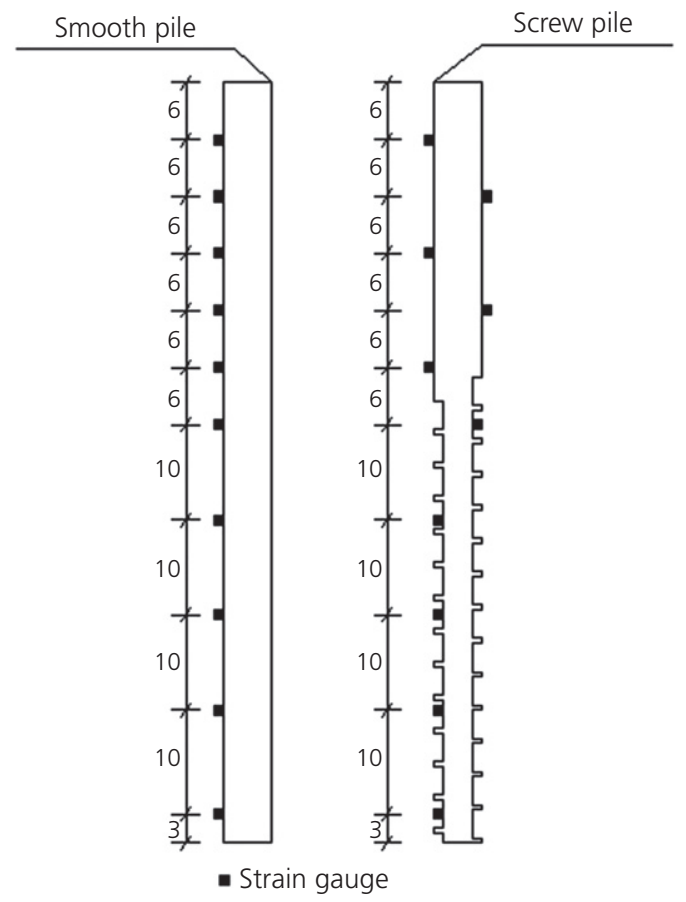

Figure 2. Layout of strain gauges

capacity tests. The top of the pile laying had a layer thickness of $1 \mathrm{~cm}$, and the grain size in the $2-5 \mathrm{~mm}$ range between the fine particles of stone served as a cushion layer, with a steel plate of size $15 \mathrm{~cm} \times 20 \mathrm{~cm}$.

The filling was levelled and compacted at each $10 \mathrm{~cm}$ depth. According to field measurement results of moisture contents and densities, the control moisture content was set to be $17 \cdot 8 \%$ and the control degree of compaction was set to be $0 \cdot 8$. Two soil samples were taken with a ring knife at the bottom at locations 30, 70 and $110 \mathrm{~cm}$ from the model box position to measure the water content and density of the fill. The 
Table 1. Mechanical properties of silty soil

\begin{tabular}{|lcccccc|}
\hline $\begin{array}{l}\text { Maximum dry } \\
\text { density: } \mathbf{g} / \mathbf{c m}^{3}\end{array}$ & $\begin{array}{c}\text { Optimum water } \\
\text { content: } \%\end{array}$ & $\begin{array}{c}\text { Plastic } \\
\text { limit: } \%\end{array}$ & $\begin{array}{c}\text { Liquid } \\
\text { limit: } \%\end{array}$ & $\begin{array}{c}\text { Internal friction } \\
\text { angle: }\end{array}$ & $\begin{array}{c}\text { Cohesion: } \\
\mathbf{k P a}\end{array}$ & $\begin{array}{c}\text { Compression } \\
\text { modulus: } \mathbf{M P a}\end{array}$ \\
\hline 1.82 & 18.17 & 17.07 & 25.33 & 24.84 & 38.52 & $2 \cdot 10$ \\
\hline
\end{tabular}

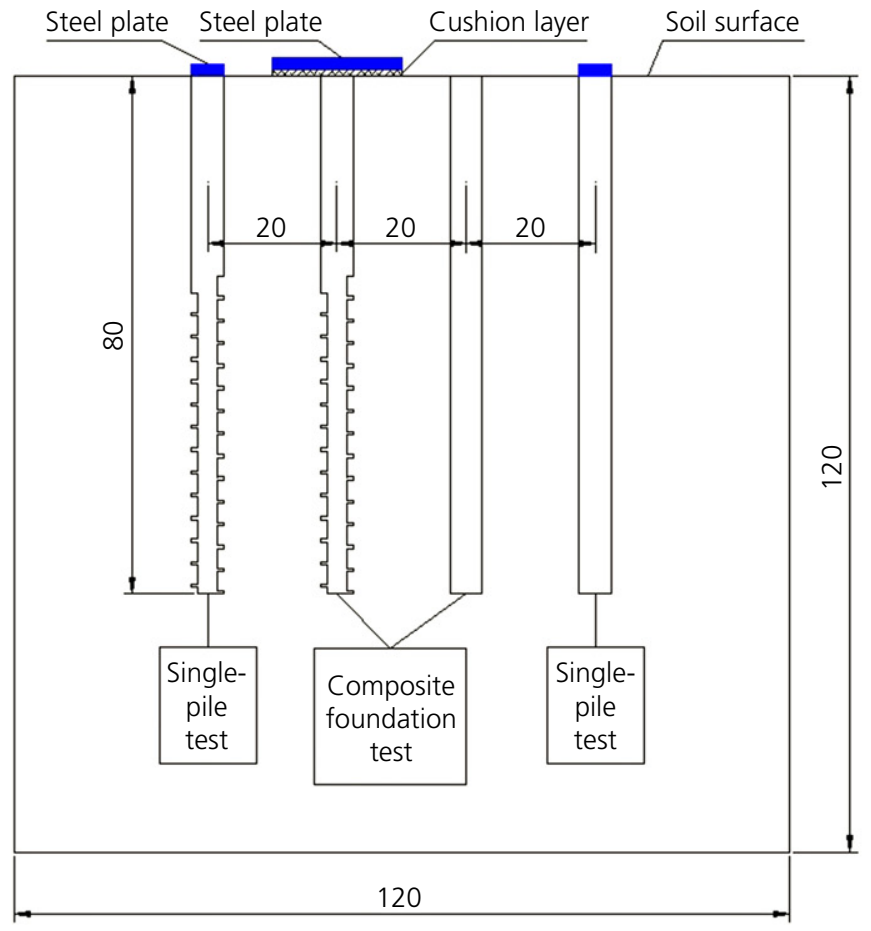

(a)

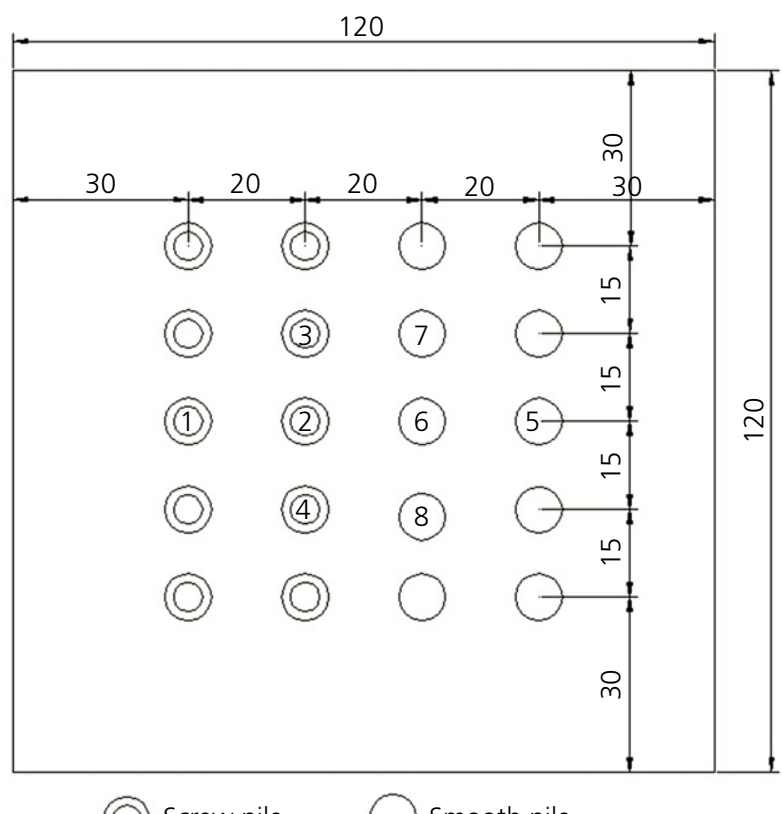

(O) Screw pile $\bigcirc$ smooth pile

(b)

Figure 3. Arrangement plan of model piles: (a) planar graph; (b) profile graph (dimensions in $\mathrm{cm}$ )

water content of the fill was determined to be $17 \cdot 72 \%$ and the density was $1.46 \mathrm{~g} / \mathrm{cm}^{3}$.

The load system consisted of a jack and reaction frame. The loading method was to slowly maintain the load, which was increased by steps in the course of the test until the load of each stage reached a relatively stable level; then, subsequent stages were loaded to the point of failure. The last stage involved completely removing the load.

\section{Analysis of the bearing capacity of a single pile}

3.1 Vertical load-settlement curves of the single pile Vertical load-settlement curves $(Q-S$ curves) of the single pile are shown in Figure 4. The figure shows that when the vertical load was small, the pile-side friction force gradually increased with increasing vertical displacement, and the $Q-S$ curve is a smooth line. As the vertical load increased gradually, the $Q_{-S}$ curves become non-linear. With a further increase in vertical load, the sharp change in the slope of the

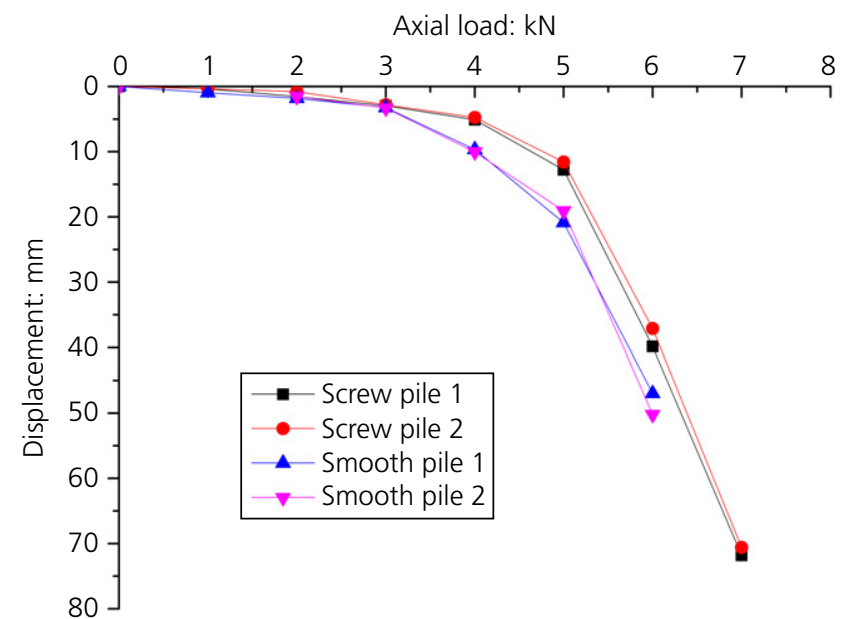

Figure 4. Axial load plotted against settlement

$Q-S$ curves and the subsequent sharp drop indicate that the lateral resistance is fully engaged and that the pile has been damaged. For the same displacement increment and the same 
axial load, the ultimate bearing capacity of the single screw pile and the single smooth pile was determined to be 5 and $3 \mathrm{kN}$, respectively. The ultimate bearing capacity of the single screw pile was thus $67 \%$ higher than that of the smooth pile.

\subsection{Axial force of single pile}

The axial force distribution curves are shown in Figures 5 and 6 . The axial force of the single-pile shaft decreased along the pile body. The screw axial force shows a clear change in slope between the smooth-rod section and the screw section of the junction $(30 \mathrm{~cm})$. The axial force of the pile decreased substantially. In the section of the screw pile, the axial force of the pile decreased to a small extent, indicating that a mechanical bite force existed between the thread and the soil, enabling the end resistance of the threaded blade and the pile end resistance to share the upper load, which reduced the degree of axial force reduction.

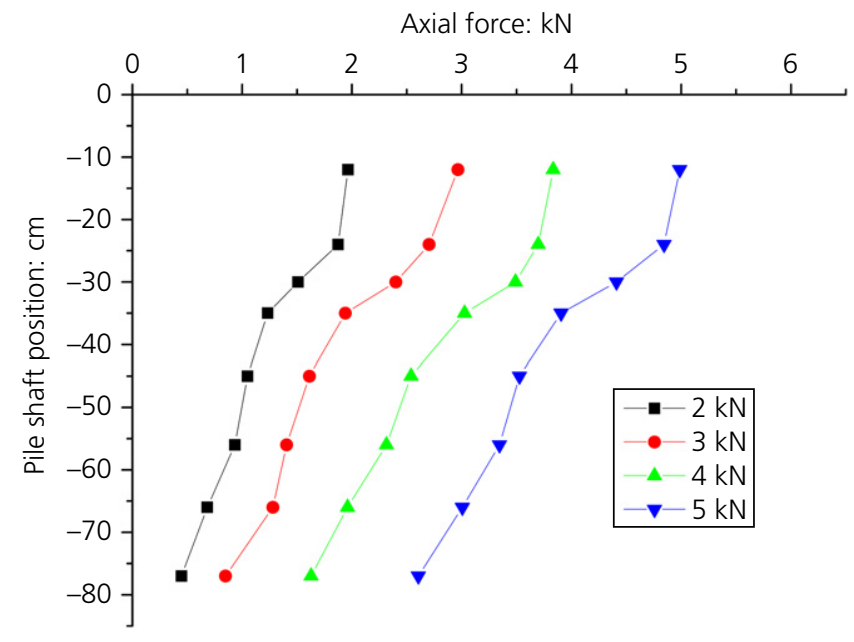

Figure 5. Axial force distribution curves of smooth pile

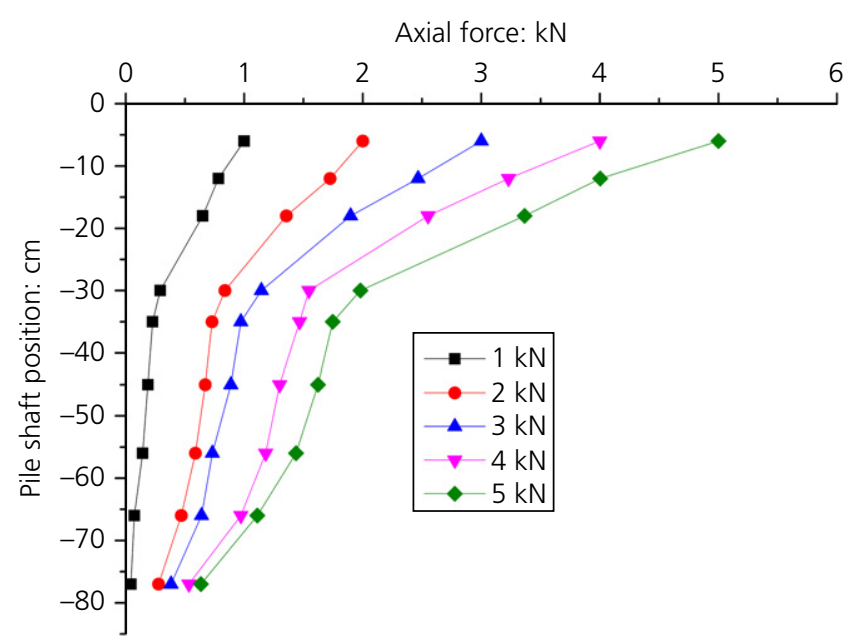

Figure 6. Axial force distribution curves of screw pile

\subsection{Side friction resistance of a single pile}

The side friction resistance distribution curves are shown in Figures 7 and 8 . The pile-side friction developed along the direction of the pile depth from the top down gradually and reached the maximum friction value at the midpoint $(\sim-40 \mathrm{~cm})$ of the pile. The distribution of the pile-side friction resistance of the smooth section of the screw rod is similar to that of the smooth pile. The friction resistance of the pile side reached its maximum at the mid-point of the smooth bar section $(\sim-18 \mathrm{~cm})$ and was attenuated along the smooth section and the screw section, resulting in play in the screw section.

\section{Analysis of the bearing capacity of the composite foundation}

\subsection{Pressure-settlement curves of the pile composite} foundations

Pressure-settlement curves ( $p-s$ curves) of the composite foundations are shown in Figure 9. When the loading reached

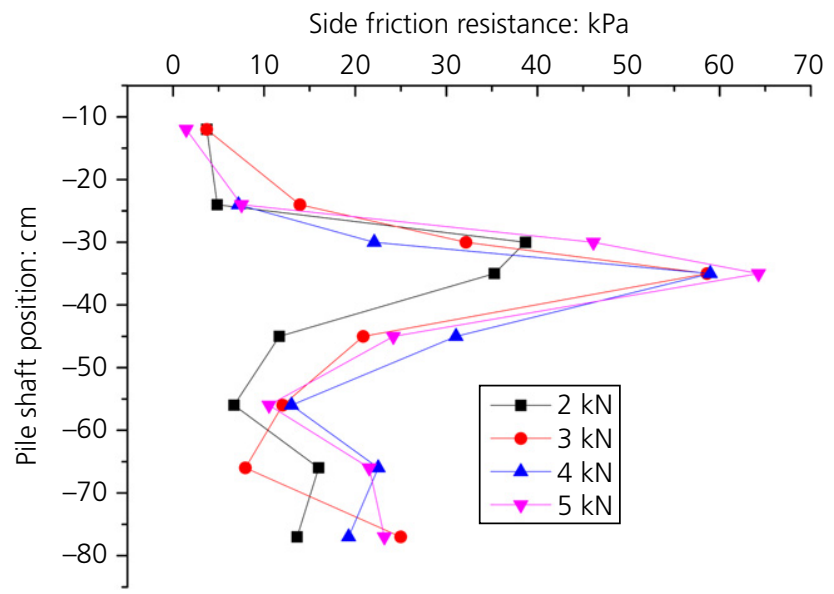

Figure 7. Side friction resistance distribution curves of smooth pile

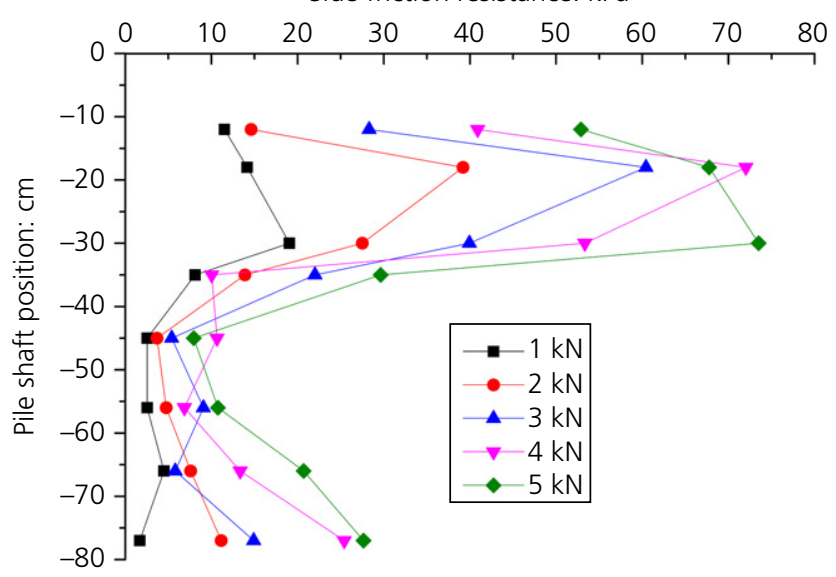

Figure 8. Side friction resistance distribution curves of screw pile 


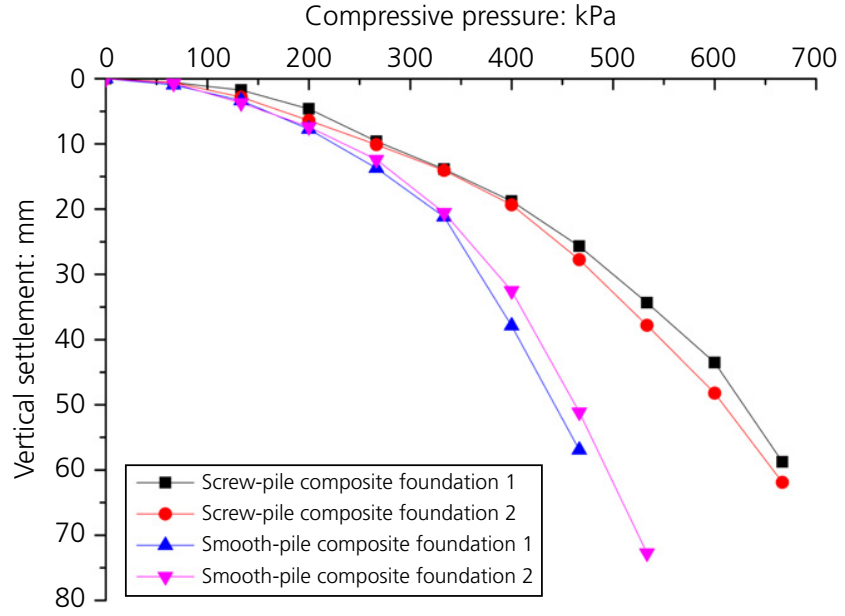

Figure 9. $p-s$ curves of the composite foundations

$133 \mathrm{kPa}$, the settlement of the two kinds of pile types was similar. When the load exceeded $133 \mathrm{kPa}$, the settlement of the smooth pile was clearly larger than that of the screw pile. The settlement of the smooth-pile composite foundation was $66.59 \mathrm{~mm}$ when it was loaded to $500 \mathrm{kPa}$ and the settlement of the screw-pile composite foundation was $61.91 \mathrm{~mm}$ when it was loaded to $667 \mathrm{kPa}$, which indicates that the bearing capacity of the composite foundation of the screw pile was higher than that of the smooth pile. Based on the $s-\log t$ curve, it was concluded that the ultimate bearing capacity of the composite foundation of the single smooth pile was $233 \mathrm{kPa}$ and the ultimate bearing capacity of the composite foundation of the screw pile was $333 \mathrm{kPa}$. The bearing capacity of the natural foundation was $167 \mathrm{kPa}$, and the ultimate bearing capacity of the smooth single-pile composite foundation was $40 \%$ higher than that of the natural foundation. The ultimate bearing capacity of the composite foundation of the single screw pile was more than $100 \%$ larger than that of the natural foundation. The ultimate bearing capacity of the screw pile composite foundation was $43 \%$ higher than that of the smooth pile composite foundation (Figure 10).

\subsection{Axial forces of the single-pile composite foundation}

The axial force distribution of the single-pile composite foundation and the axial force distribution of the single pile in the single-pile composite foundation were found to be considerably different. The smooth pile's axial force first increased and then decreased with depth, with the maximum axial force appearing at approximately $35 \mathrm{~cm}$ depth from the top of the pile. Thus, a negative friction zone existed in the smooth-pile composite foundation, consistent with the results of other smooth-pile composite foundation tests (Zhang et al., 2011).

The axial force distribution of the smooth pile was similar to that of the composite pile axial force distribution shown in

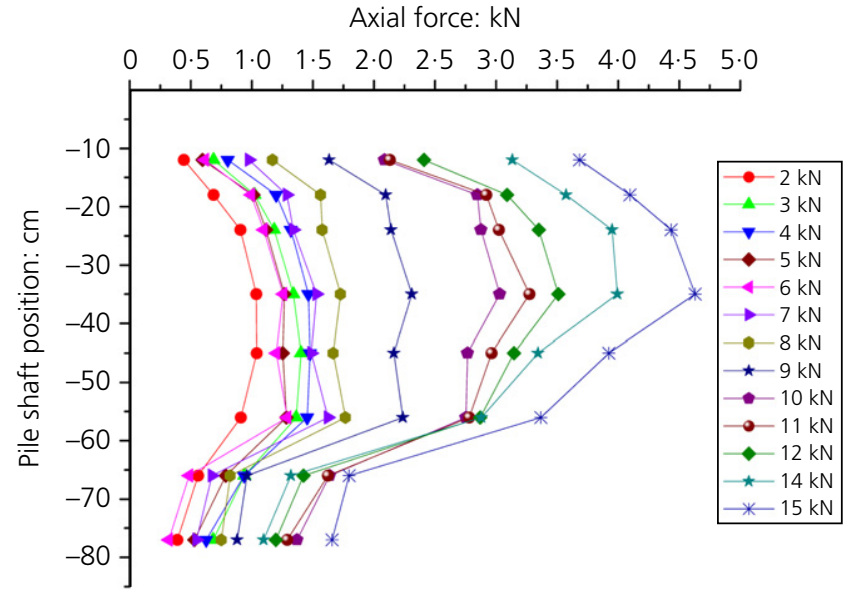

Figure 10. Axial force distribution of the smooth-pile composite foundation

Figure 11. At $30 \mathrm{~cm}$ depth, the axial force exhibited a clear inflection point and the axial force of the pile body was applied to the variable cross-section, which is consistent with the law of axial force transmission of a pile with a variable cross-section (Luo et al., 2012). This finding shows that a partial load was transmitted to the screw section and that the mechanical resistance of the screw thread to the soil plays the role of an end bearing.

\subsection{Pile-side friction resistance of the composite foundations}

Analysis of Figures 12 and 13 (side friction resistance distribution of the single-pile composite foundation) indicates that a negative friction zone existed $(\sim 30-40 \mathrm{~cm})$ below the junction point of the smooth segment and the screw section of the

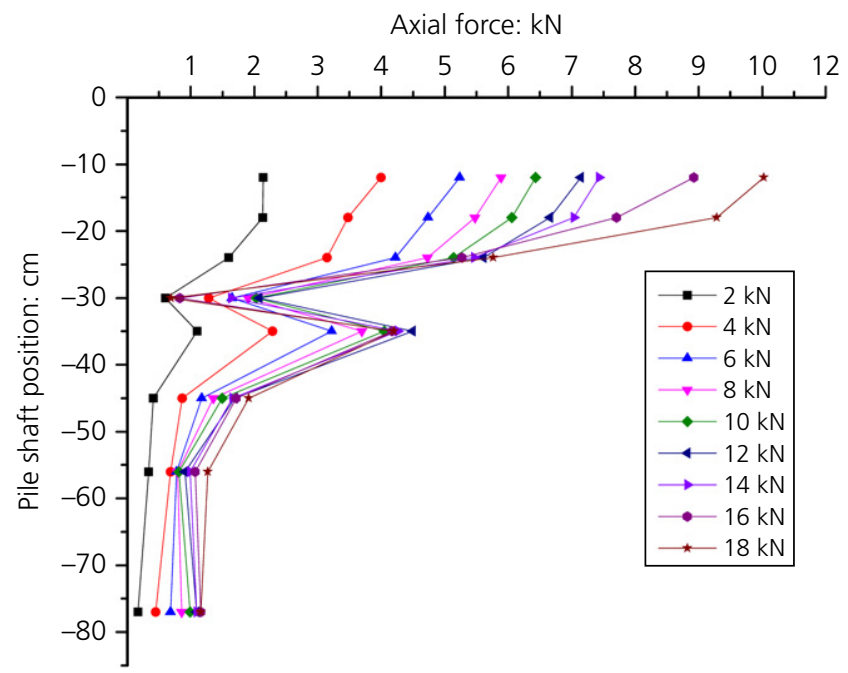

Figure 11. Axial force distribution of the screw-pile composite foundation 
Side friction resistance: $\mathrm{kPa}$

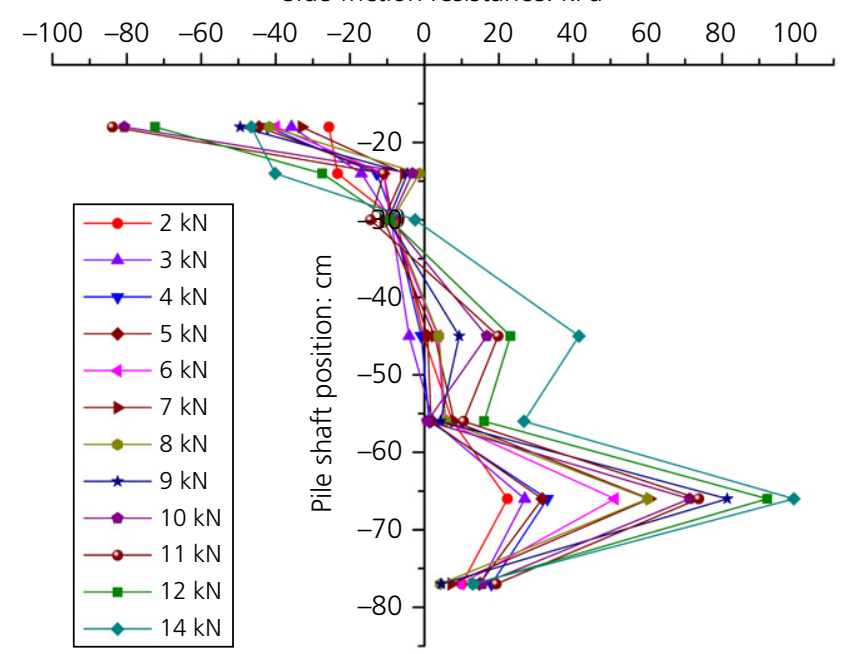

Figure 12. Pile-side friction resistance of the smooth-pile composite foundation

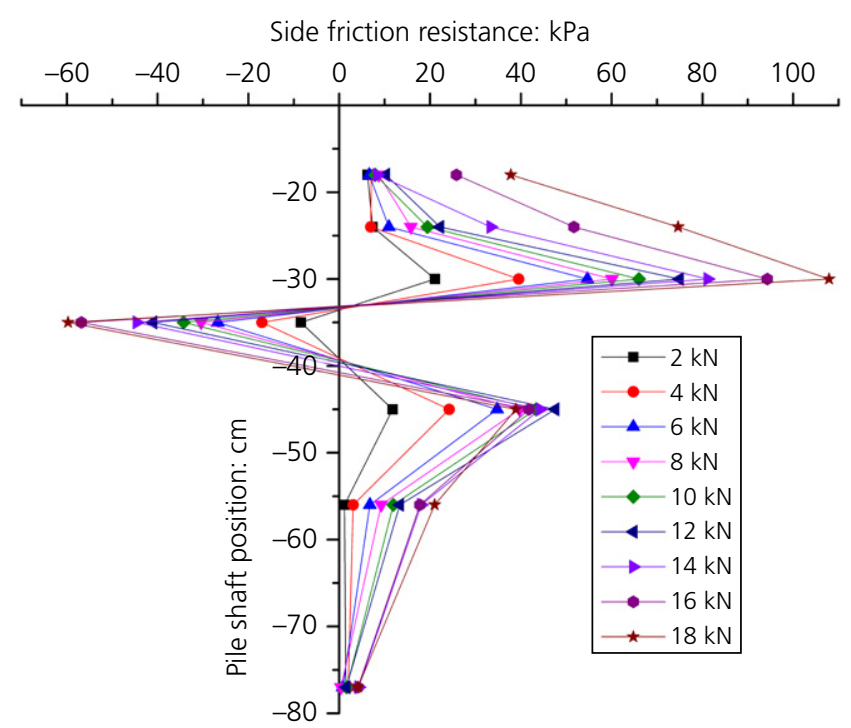

Figure 13. Pile-side friction resistance of the screw-pile composite foundation

screw-pile composite foundation. This zone arises primarily because the smooth segment section causes the pile-side resistance to gradually increase to its full extent; the area of the pile body and the soil mass decreases sharply, and the soil under the smooth-rod section has a larger supporting effect. Thus, the distribution direction of friction resistance is changed, and a negative friction resistance zone appears.

For the smooth-pile composite foundation, the pile-side friction changed from positive to negative, which is due primarily to the pile stiffness under load on the pile top; the deformation was greater in the pile than in the soil between the piles and

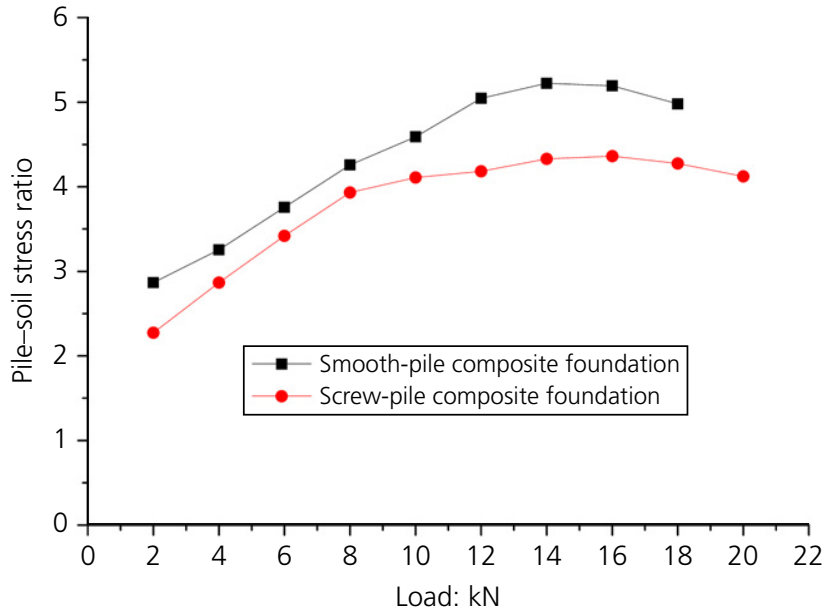

Figure 14. Pile-soil stress ratio of the composite foundations

the negative friction resistance increased with increasing depth. The pile-soil stress decreased, reducing the deformation of the soil, and the pile and soil moved downward relative to the pileside frictional resistance, which becomes positive, to prevent sinking of the pile.

Figure 14 shows the pile-soil stress ratio of the composite foundation, for smooth piles and screw piles, which indicates that the pile-soil stress ratio increased with increasing external load but ultimately tended to stabilise. The results show that when the load was small, the load on the soil between piles was larger; with increasing load, the load is transferred to the pile top. When the load increases to a certain extent, the deformation of the pile and soil becomes coordinated, and the load sharing between pile and soil tends to stabilise (Liu and Zhang, 2004). The load ratio of the screw pile was $69-81 \%$ and the load-sharing ratio between the pile and the soil was $19-31 \%$. The stress ratio of smooth pile was $2 \cdot 86-5 \cdot 22$, the load-sharing ratio of the smooth piles was $74-83 \%$, and the load-sharing ratio between the piles was $17-26 \%$, which indicates that screw piles can better adjust the pile bearing capacity. In effect, this mechanism improves the bearing capacity of the composite foundation.

\section{Discussion}

(a) A screw pile has a variable cross-section, which satisfies the distribution law of additional stress and the requirement of stress-sharing ratio and stiffness change. Influenced by its structural shape, the effect between soil and pile is adjusted, the stress-sharing ratio and stress diffusivity of the pile-side soil are increased and the load on the pile end is reduced, which means that the bearing capacity of the pile is consistent with the soil stress. 
(b) The model test results of Chen et al. (2017) and the in situ test results of Pei-Hong et al. (2016) showed that the stress characteristics of the upper smooth-rod section are the same as those of an ordinary cast-in-place pile and the bearing mechanism of the lower thread section differs from that of smooth piles due to the mechanical bite force between the thread and the soil. Generally, the bearing capacity of a screw pile is composed of four parts: the side friction resistance of the upper smooth bar, the side friction resistance of the lower thread section, the end resistance of the screw blade and the end resistance of the bottom of the pile. The ultimate value of the bearing capacity of the screw pile is equal to the sum of their limit values.

\section{Conclusions}

(a) Relative to the smooth pile, the ultimate bearing capacity of the single screw pile was $67 \%$ greater for the same pile diameter and length. The shaft axial force of the smooth rod decreased along the pile length and a clear change in slope appeared between the smooth section and the screw section.

(b) Relative to the smooth pile, the bearing capacity of the screw-pile composite foundation with a single-pile limit increased by $43 \%$. The screw-pile soil stress ratio was found to be in the range $2 \cdot 27-4 \cdot 33$ and the smoothpile soil stress ratio varied from $2 \cdot 86$ to $5 \cdot 22$. This means that a screw-pile can better adjust the play effect of the bearing capacity of soil between the piles and improve the bearing capacity of the composite foundation relative to the smooth pile.

(c) The axial force distributions of the screw-pile composite foundation and the single pile were similar and consistent with the axial force of the variable-section pile transfer law. The axial force distributions of the smooth-pile composite foundation and the single pile were different, with the axial force of the pile depth first increasing and then decreasing. A negative friction area was found to exist in the composite foundation top.

(d) There was negative friction area under the junction point between the smooth-rod section and the screw section in the screw-pile composite foundation, indicating that the damage from negative friction resistance on the pile structure should be investigated to enhance the treatment of variable cross-sections in engineering design and construction.

\section{Acknowledgement}

Financial support from the National Natural Science Foundation of China (grant numbers 41402252, 41662017 and 51668036) is gratefully acknowledged.

\section{REFERENCES}

Chen Y, Wang A, Cai J and Sun H (2017) Experimental on bearing and deformation behavior of half-screw pile under vertical load. Construction Technology 46(14): 116-119.

Deng RF (2016) Construction technique of half-screwed filling pile and its application in railway engineering. Railway Construction Technology 33(4): 84-87.

Dong TW, Liang L, Wang W and Wang MS (2008) Experimental analysis on the lamina-soils interaction in pullout screw pile foundation. Engineering Mechanics 25(8): 150-155.

Kurian NPKP and Shah SJSJ (2009) Studies on the behavior of screw piles by the finite element method. Canadian Geotechnical Journal 46(6): 627-638.

Lee CW, Kim YS and Park SY (2016) Development of prebored screw pile method and evaluation of its bearing characteristics. Marine Georesources \& Geotechnology 34(1): 42-56.

Liu J and Zhang KN (2004) Load transfer law and deformation calculating of the composite foundation. China Journal of Highway \& Transport 17(1): 20-23.

Liu Z (2015) Application research of screw pile in deep fill foundation reinforcement. Resources Environment \& Engineering 29(3): 323-326.

Luo DS, Xiao C, Zhang KN, He J and Chen XG (2012) Load transfer mechanism of T-shaped soil-cement deep mixing pile in Nansha area, Guangzhou. Journal of Central South University 43(9): 3575-3581.

Meng Z, Chen JJ, Wang JH and Yin ZY (2012) Study of model test on bearing capacity of screw piles in sand. Rock and Soil Mechanics 33(s1): 141-145.

Pei-Hong XU, Bin XU and Dong TW (2016) The analysis of the bearing capacity of screw piles on static loading tests. Journal of Transport Science \& Engineering 32(3): 58-62.

Qian J, Wang B, Chen H and Huang M (2015) Model test and bearing mechanism study on grouting-screw uplift piles. Journal of Building Structures 36(10): 146-152.

Rao SN, Prasad YVSN and Shetty MD (2008) The behavior of model screw piles in cohesive soils. Soils \& Foundations 31(2): 35-50.

Sakr MS (2009) Performance of helical piles in oil sand. Canadian Geotechnical Journal 46(9): 1046-1061.

Stanier SA, Black JA and Hird CC (2014) Modelling helical screw piles in soft clay and design implications. Geotechnical Engineering 167(5): $447-460$.

Wan PZ (2016) Key construction techniques and bearing behaviors of railway foundation treatment with screw pile in saline soil area. Railway Construction Technology 33(5): 82-86.

Zhang JW, Zeng JC, Tu YM and Tong XD (2011) Experimental study on CFG pile-raft composite foundation of Beijing-Shanghai highspeed railway. Journal of the China Railway Society 33(1): 83-88.

\section{How can you contribute?}

To discuss this paper, please email up to 500 words to the editor at journals@ice.org.uk. Your contribution will be forwarded to the author(s) for a reply and, if considered appropriate by the editorial board, it will be published as discussion in a future issue of the journal.

Proceedings journals rely entirely on contributions from the civil engineering profession (and allied disciplines). Information about how to submit your paper online is available at www.icevirtuallibrary.com/page/authors, where you will also find detailed author guidelines. 